\title{
HUMAN RELATIONS SEBAGAI PENUNJANG KOORDINASI DALAM PENYELENGGARAAN DI WILAYAH PEMERINTAHAN KABUPATEN SORONG (Studi di Distrik Mariat)
}

\author{
Saiful Ichwan \\ Program Studi Administrasi Negara, FISIP, Universitas Muhammadiyah Sorong
}

\begin{abstract}
ABSTRAK
Secara sekilas human relations terlihat sebagai suatu hal yang biasa dan mudah dilakukan, tetapi sebenarnya tidaklah demikian adanya. Human relations adalah suatu hal yang dinamis dan tidak terlepas dari faktor manusia. Hubungan kerja antara atasan dengan bawahan misalnya. Komunikasi, tugas, dan tanggung jawab atau pendelegasian wewenang akan sangat sulit dilakukan jika tidak dibarengi dengan proses human relations yang baik. Disadari atau tidak, human relations dapat memberi pengaruh-pengaruh positif terhadap motivasi kerja seseorang. Teknik-teknik yang kurang tepat yang digunakan oleh seorang atasan dalam berkomunikasi dengan bawahannya komunikasi vertikal akan berakibat menurunnya motivasi kerja bawahannya. Hal ini dapat terjadi karena motivasi berhubungan erat dengan implikasi-implikasi yang diterima sebagai hasil suatu komunikasi. Adapun komunikasi horizontal dalam berkomunikasi yaitu berupa koordinasi tugas, penyelesaian masalah, pembagian informasi, dan resolusi konflik. Kantor Distrik Mariat Kabupaten Sorong adalah salah satu instansi pemerintah yang mempunyai organisasi yang cukup baik, dimana kegiatan-kegiatan kerja dilimpahkan kepada seluruh pegawai, baik pegawai tetap (PNS) maupun pegawai honorer.
\end{abstract}

Kata Kunci: Human relations, Koordinasi , Penyelenggaraan Pemerintahan.

\section{PENDAHULUAN}

Human relations secara harfiah

berarti komposit dari interaksi antar manusia, dalam segala aspek kehidupan. Human relations ini biasa disebut juga dengan hubungan interpersonal. Kemampuan dalam melakukan hubungan interpersonal ini sangat penting demi keberhasilan individu di dalam semua lapangan kehidupan, baik dalam kehidupan personal atau profesional seperti dalam dunia kerja. Khususnya dalam suatu organisasi atau suatu instansi, tanpa kemampuan hubungan interpersonal yang baik, para manajer, pejabat publik ataupun staf biasa, akan mengalami kegagalan, karena kesulitan di dalam memberikan pelayanan yang optimal.

Dalam

penyelenggaraan pemerintahan Kabupaten Sorong, khusus di Kecamatan/Distrik Mariat memerlukan adanya seorang pemimpin yang selalu mampu untuk menggerakkan bawahannya agar dapat melaksanakan tugas dan tanggung jawabnya untuk berpartisipasi 


\section{Jurnal Noken, Volume 4 (1) Halaman 12-22 2018}

dalam kegiatan pemerintahan, pembangunan dan kemasyarakatan secara berdayaguna dan berhasil guna. kelancaran penyelenggaraan tugas pemerintahan dan pembangunan nasional sangat tergantung pada kesempurnaan aparatur negara khususnya pegawai negeri.

\section{Kecamatan/Distrik Mariat}

Kabupaten Sorong dilihat dari sistem pemerintahan Indonesia, merupakan ujung tombak dari pemerintahan daerah yang langsung berhadapan dengan masyarakat luas. Citra birokrasi pemerintahan secara keseluruhan akan banyak ditentukan oleh kinerja organisasi tersebut. Masyarakat perkotaan yang peradabannya sudah cukup maju, mempunyai kompleksitas permasalahan lebih tinggi dibandingkan pada masyarakat tradisional sehingga diperlukan aparatur pelayanan yang profesional.

Sebagai suatu disiplin ilmu maka human relations adalah suatu studi tentang hubungan antar manusia yang mencakup semua bentuk interaksi manusia dalam kehidupan bermasyarakat. Potensi aktualitas dan proses kreativitas manusia perlu digali, diarahkan dan dikembangkan di dalam wadah masyarakat dan juga organisasi.Peran human relations sangat menentukan aktifitas organisasi dalam mencapai tujuannya. Oleh karena itu, human relations harus memiliki evaluasi prestasi kerja bagi seluruh orangorang yang ada di dalam organisasi, sehingga organisasi tersebut dapat mengetahui sejauh mana tingkat pencapaian prestasinya dan hal ini dapat dijadikan tolak ukur untuk pemberian kompensasi. Pengembangan potensi diri serta perbaikan lingkungan kerja dalam melakukan inovasi yang akhirnya akan meningkatkan motivasi dan juga meningkatkan prestasi kerjanya, maka organisasi harus memberikan insentif atau membuat kebijakan tertentu dalam rangka memotivasi pegawainya, agar dapat memberikan kontribusi balikan kepada organisasi, yaitu berupa prestasi kerja yang tinggi.

Di dalam konsep ilmu pengetahuan disiplin ilmiah human relations termasuk dalam lingkungan ilmu-ilmu sosial dan mengalami perkembangan di bidang sosiologi, ilmu jiwa sosial, ilmu politik, dan manajemen. Sejalan dengan perkembangan organisasi lembaga, perusahaan dan industriindustri maupun dalam lembaga pemerintahan yang menggunakan teknik manajemen yang akurat serta tepat guna.

Kenyataannya pendekatan human relations bukan merupakan suatu keadaan yang positif melainkan suatu aktifitas yang 


\section{Jurnal Noken, Volume 4 (1) Halaman 12-22 2018}

dinamis, yaitu suatu kegiatanuntuk mengembangkan hasil atau prestasi yang lebih produktif dan efektif. Bila dipandang dari seorang pemimpin yang bertanggung jawab untuk memimpin suatu organisasi atau kelompok.Seorang atasan yang mendapat umpan balik dari bawahannya, hendaknya menerima secara seksama.

Hambatan human relations pada umumnya merupakan gangguan, penentangan terhadap suatu usaha komunikasi agar gangguan dan penentangan ini biasanya disebabkan karena adanya pertentangan kepentingan, tamak, iri hati, apatisme dan sebagainya aktor kepentingan dan prasangka merupakan faktor yang paling berat karena usaha yang paling sulit bagi seorang komunikator ialah mengadakan komunikasi dengan orang yang jelas tidak menyenangi komunikator atau menyajikan pesan komunikasi yang berjalanan dengan fakta atau isinya yang mengganggu suatu kepentingan apabila seseorang dikonfrontasikan dengan suatu bentuk komunikasi yang tidak disukainya karena mengganggu kepentingannya maka orang tersebut biasanya mencemoohkan komunikasi tersebut.

Berdasarkan latar belakang diatas, penulis bermaksud meneliti dengan judul: 'Human Relations Sebagai Penunjang
Koordinasi Dalam Penyelenggaraan di Wilayah Pemerintahan Kabupaten Sorong (Studi di Distrik Mariat)".

\section{KAJIAN PUSTAKA}

Menurut Ali (2006:141), human relations di artikan sebagai keseluruhan rangkaian hubungan, baik yang bersifat formal, antara atasan dengan bawahan, serta bawahan yang lain yang harus dibina dan di pelihara sedemikian. rupa sehingga tercipta suatu team work dan suasana kerja yang intim dan harmonis dalam rangka pencapaian tujuan.

Menurut H.A.W. Widjaja (2002:164), human relations dalam arti luas yaitu hubungan antara seseorang dengan orang lain yang terjadi dalam segala situasi dan dalam semua bidang kegiatan atau kehidupan untuk mendapatkan kepuasan hati. Human relations dalam arti sempit yaitu hubungan antara seseorang dengan orang lain dalam suatu organisasi kantor yang bertujuan memberikan kepuasan hati para karyawan sehingga para karyawan itu mempunyai semangat kerja yang tinggi.

Human relations adalah motivasi manusia dalam organisasi membangun kerjasama yang secara efektif mengisi kebutuhan-kebutuhan dan penerimaan 


\section{Jurnal Noken, Volume 4 (1) Halaman 12-22 2018}

tujuan-tujuan organisasi. Human relations

sudah banyak diterapkan dalam kehidupan organisasi, baik swasta maupun pemerintahan namun kenyataan menunjukkan bahwa tidak sedikit pula instasi atau lembaga pemerintah yang kurang memperhatikan aspek-aspek tertentu dari pendekatan human relations, terutama yang berkaitan dengan masalah kebutuhan yang bersifat psikologis, sosial dan batiniah.

Koordinasi berasal dari kata coordination, co dan ordinare yang berarti pendekatan empirik yang dikaitkan dengan etimologi, koordinasi diartikan sebagai kegiatan yang dilakukan oleh berbagai pihak yang sederajat untuk saling memberi informasi dan mengatur /menyepakati hal tertentu (Ndraha taliziduhu 2003:290) Secara normatif, koordinasi diartikan sebagai kewenangan untuk menggerakkan, menyerasikan, menyelaraskan, dan menyeimbangkan kegiatan-kegiatan yang spesifik atau berbeda-beda agar semuanya terarah pada tujuan tertentu.

Sedangkan secara fungsional, koordinasi dilakukan guna untuk mengurangi dampak negatif spesialisasi dan mengefektifkan pembagian kerja. Menurut Ndraha Taliziduhu dalam bukunya yang berjudul Kybernology (2003:293) : Koordinasi dapat didefinisikan sebagai proses penyepakatan bersama secara mengikat berbagai kegiatan atau unsur yang berbeda-beda sedemikian rupa sehingga di sisi yang satu semua kegiatan atau unsur itu terarah pada pencapaian suatu tujuan yang telah ditetapkan dan di sisi lain keberhasilan yang satu tidak merusak keberhasilan yang lain. Menurut Leonard D. White (dalam Inu Kencana, 2011:33) : Koordinasi adalah penyesuaian diri dari masing-masing bagian, dan usaha menggerakkan serta mengoperasikan bagian-bagian pada waktu yang cocok, sehingga dengan demikian masing-masing bagian dapat memberikan sumbangan terbanyak pada keseluruhan hasil yang telah di capai.

Koordinasi menurut Awaluddin Djamin dalam Hasibuan (2011:86) diartikan sebagai suatu usaha kerja sama antara badan, instansi, unit dalam pelaksanaan tugas-tugas tertentu, sehingga terdapat saling mengisi, saling membantu dan saling melengkapi. Dengan demikian koordinasi dapat diartikan sebagai suatu usaha yang mampu menyelaraskan pelaksanaan tugas maupun kegiatan dalam suatu organisasi.

Sistem Penyelenggaraan Pemerintahan Negara pada hakikatnya merupakan uraian tentang bagaimana mekanisme pemerintahan negara dijalankan oleh Presiden sebagai pemegang kekuasaan 


\section{Jurnal Noken, Volume 4 (1) Halaman 12-22 2018}

pemerintahan Negara. $\quad$ Sistem

Penyelenggaraan Pemerintahan Negara

adalah sistem bekerjanya pemerintahan sebagai fungsi yang ada pada Presiden.

Pada dasarnya Sistem Penyelenggaraan Pemerintahan Negara tidak membicarakan Sistem Penyelenggaraan Pemerintahan oleh lembaga - lembaga Negara secara keseluruhan. Dalam arti sempit, istilah penyelenggaraan Negara tidak mencakup lembaga lembaga yang tercantum dalam undang undang dasar 1945. dalam arti luas untuk istilah penyelenggaraan Negara yang mengacu pada tataran supra struktur politik.

\section{METODE PENELITIAN}

\section{Lokasi Penelitian}

Lokasi penelitian merupakan suatu tempat atau wilayah dimana penelitian akan dilakukan. Adapun tempat penelitian yang akan dilakukan oleh penulis berlokasi di Distrik Mariat Kabupaten Sorong.

\section{Jenis Penelitian}

Dalam penelitian ini metode kualitatif terdapat beberapa sumber data. Sumber data tersebut dapat berupa manusia, peristiwa atau aktivitas, tempat atau lokasi, benda, beragam gambar dan rekaman, dokumen atau arsip, menurut Branne, Julia, (2005:50).

Jenis yang di lakukan dalam penelitian ini adalah kualitatif dengan pendekatan analisis deskriptif. Data yang di peroleh akan dianalisis serta di deskrisipsikan berdasarkan penemuan faktafakta penelitian di lapangan. Pendekatan inilah yang akan dipergunakan dalam menjelaskan fenomena dan menganalisis peranan, kendala, solusi, dan strategis human relations sebagai penujang koordinasi dalam penyelenggaraan di wilayah Distrik Mariat Kabupaten Sorong.

\section{Teknik Analisis Data.}

Analisis data yang dilakukan sejak awal pengumpulan data sampai akhir penelitian. Hal ini di lakukan agar data yang di peroleh dapat dilakukan pengecekan kembali di lingkungan seandainya data itu belum lengkap atau data yang masih di ragukan kebenarannya. Teknik analisis data di lakukan dengan cara kualitatif.

\section{HASIL PEMBAHASAN}

Dalam konteks pemerintahan, relasi human relations dalam penyelenggaraan pemerintahan sangat memberikan dampak yang besar bagi para aparatur pemerintahan. Jika aparatur pemerintahan dapat mempraktekkan human 


\section{Jurnal Noken, Volume 4 (1) Halaman 12-22 2018}

relations dengan baik, maka akan sangat memberikan pengaruh kepada kualitas kebijakan dan hasil yang baik bagi kehidupan masyarakat. Dalam lingkup pemerintahan Distrik Mariat Kabupaten Sorong human relations bisa membantu aparat pemerintah Distrik dalam mengembangkan Distrik dan mensejahterakan masyarakat.

Dalam sebuah wawancara dengan Amat Daroji, S.AN. (Kepala Distrik Mariat Kabupaten Sorong): memberikan komentarnya mengenai fungsi human relations ini, dimana beliau mengatakan sebagai beriku:

" .......Bahwa fungsi human relations yaitu adanya suatu interaksi, atau hubungan yang pasif, dalam suatu aktivitas penyelenggaraan pemerintahan untuk mengembangkan hasil yang lebih produktif dan memuaskan oleh karena itu kehadiran human relations dalam sistem manajemen suatu lembaga sudah layaknya secara optimaluntuk membangun suasana akrab dalam kerja sama yang dapat memberikan motivasi dalambekerja dengan perasaan puas".

Dalam wawancara di atas, secara tidak langsung memberikan penjelasan bahwa fungsi human relations sebagai penunjang koordinasi penyelenggaraan pemerintahan Distrik Mariat Kabupaten Sorong.
Dalam hubungannya dengan manajemen sumber daya manusia, komunikasi yang dalam hal ini humanrelations bukan hanya sekedar berarti pengiriman dan penerimaan pesan, tetapi lebih jauh dari itu, karenahuman relations juga bertujuan mengembangkan potensi sumber daya manusia. Sesuai dengan tujuan tersebut, pengembangan potensi pegawai dalam suatu pemerintahan tidak akan terlepas dari upaya peningkatan prestasi kerja seorang pegawai. Seorang pegawai yang baik akan memberikan kontribusi yang lebih besar terhadap keefektifan organisasinya. Jika seorang pegawai termotivasi dengan baik, maka akan menunjukkan suatu pemerintahan yang berjalan efektif dan hal ini merupakan kunci sukses bagi seorang atasan dalam membina lembaga/pemerintahan yang dipimpinnya.

Peran human relations sangat menentukan aktifitas organisasi dalam mencapai tujuannya. Oleh karena itu, human relations harus memiliki evaluasi bagi seluruh orang-orang yang ada di dalam organisasi, sehingga organisasi tersebut dapat mengetahui sejauh mana tingkat pencapaian prestasinya dan hal ini dapat dijadikan tolak ukur untuk pemberian kompensasi, maka organisasi harus 


\section{Jurnal Noken, Volume 4 (1) Halaman 12-22 2018}

memberikan insentif atau membuat kebijakan tertentu dalam rangka memotivasi pegawainya, agar dapat memberikan kontribusi balikan kepada organisasi.

Dalam sebuah wawancara dengan Winarti Mahmud, S.STP. (Sekretaris Distrik Mariat Kabupaten Sorong): memberikan komentarnya mengenai fungsi humanrelations ini, dimana beliau mengatakan bahwa:

“ Di dalam mengembangkan dan melaksanakan fungsi humanrelations di tingkat Distrik ada dua obyek yaitu: kepada para pegawai dan kepada warga masyarakat. Kepada para pegawai di bagi dua yaitu, pegawai sekretariat Distrik dan pegawai Kelurahan dan kampung. Dalam menjabarkan tugas dan fungsi kepada para pegawai dapatlah dilakukan hubungan komunikasi aktif dalam rangka memotifasi para pegawai untuk menjalani tugas kedinasan yang menjadi tanggung jawab tiap personil yang ada baik sebagai kepala seksi dan staf atau sebagai Lurah dan staf.

Pelaksanaan fungsi human relations di Pemerintahan Distrik Mariat Kabupaten Sorong, dalam pemerintahannya menunjukkan pelaksanaan relasi personal antarsesama warga masyarakat dan antara warga masyarakat dengan pemerintah sehinggamembantu proses pembangunan

masyarakat, untuk menunjukkan pelaksanaan relasi antar masyarakat dengan pemerintah yang baik. Dalam konteks pemerintahan, relasi human relations dalam penyelenggaraan pemerintahan sangat memberikan dampak yang besar bagi para aparatur pemerintahan.Jika aparatur pemerintahan dapat mempraktekkan human relations dengan baik, makaakan sangat memberikan pengaruh kepada kualitas kebijakan dan hasil yang baik bagikehidupan masyarakat. Dalam lingkup pemerintahan Distrik Mariat Kabupaten Sorong, human relations bisamembantu aparat pemerintah dalam mengembangkan Kelurahan dan Kampung untuk mensejahterakan masyarakatnya. Satu tugas pegawai Distrik Mariat adalah melakukan fungsi human relations sebagai penunjang koordinasi penyelenggaraan pemerintahan seperti yang di katakan Kepala Seksi Pemerintahan Distrik Mariat Kabupaten Sorong yaitu Muhammad Unus S,Sos:

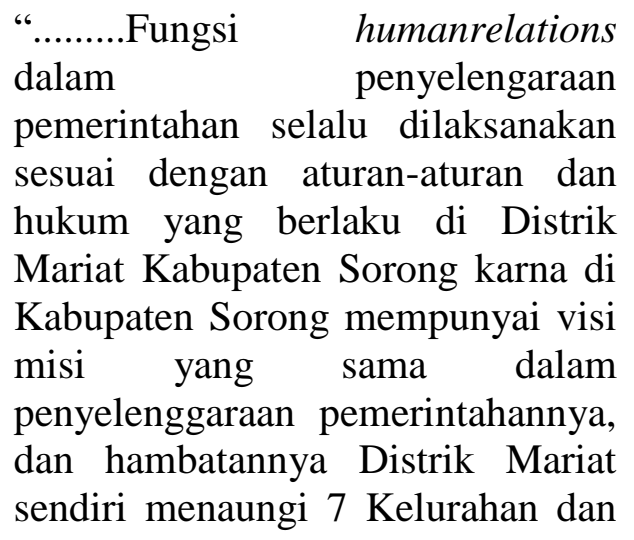




\section{Jurnal Noken, Volume 4 (1) Halaman 12-22 2018}

4 Kampung, untuk sistem komunikasinya masih kurang baik dan cepat karena masih belum memaksimalkan teknologi yang ada sekarang”.

Berdasarkan informasi yang didapatkan dari wawancara-wawancara dan studi pustaka yang dilakukan selama proses penelitian, temuan-temuan yang ditemukan pada pegawai Distrik Mariat Kabupaten Sorong dalam melakukan fungsi human relations sebagai penunjang penyelenggaraan pemerintahannya yang intens di lakukannya berupa suatu proses interaksi yang terjadi antara seseorang dengan orang lain untuk mendapatkan adanya saling pengertian, kesadaran dan kepuasan psikologis.

Bahwa komunikasi interpersonal untuk mengubah perilaku seseorang lewat interaksi untuk membangun suasana akrab dalam kerja sama yang dapat memberikan motivasi dalam bekerja dengan perasaan puas, menunjukkan bahwa perbedaanperbedaan paradigma dan persepsi antara pemerintah dan masyarakat dalam menyelenggarakan pemerintahan selayaknya dijembatani secara proporsional dan bertanggung jawab. Masing-masing aparatur Distrikmenjalankan tugasnya demi kesejahteraan masyarakat Oleh karena itu,

peran masing-masing aparatur dilakukan sesuai dengan bidangnya dengan sasaran utamanya adalah mengkomunikasikan bagi semua warga masyarakatnya.

\section{B. Faktor-faktor Menghambat Fungsi}

Human

Penyelenggaraan

\section{Distrik Mariat Kabupaten Sorong.}

Fungsi human relations dalam penyelenggaraan pemerintahan merupakan salah satu fungsi sebagai penunjang dalam penyelenggaraan pemerintahan di pengaruhi oleh beberapa faktor yang secara umum di antaranya adalah:

\section{Faktor Kondisi Sosial Budaya}

Faktor sosial budaya berkaitan dengan kultur masyarakat yang berupa persepsi/pandangan, adat istiadat, dan kebiasaan. Peserta didik selalu melakukan kontak dengan masyarakat. Pengaruhpengaruh budaya yang negatif dan salah terhadap dunia pendidikan akan turut berpengaruh terhadap perkembangan dan pertumbuhan anak. Peserta didik yang bergaul dengan teman-temannya yang tidak sekolah atau putus sekolah akan terpengaruh dengan mereka.

\section{Faktor Komunikasi Dan Informasi}

Pelaksanaan human relations dalam pemerintah Distrik Mariat Kabupaten 


\section{Jurnal Noken, Volume 4 (1) Halaman 12-22 2018}

Sorong menunjukkan pelaksanaan relasi personal antar sesama warga masyarakat dan antara warga masyarakat dengan pemerintah sehingga membantu proses pembangunan masyarakat, namun juga di lain pihak kurang menunjukkan pelaksanaan relasi antar masyarakat dengan pemerintah yang baik. Hal ini sesuai dengan hasil wawancara yang dilakukan terhadap warga masyarakat dan pemerintah Distrik Mariat kabupaten Sorong. Dari data tersebut dapat dilihat bahwa ada sebagian warga yang menyatakan bahwa selama ini pemerintah telah melakukan praktek human relations dengan baik. Humanrelations atau relasi kemanusiaan yang dilakukan selama ini sudah menyeluruh dan menyentuh segala aspek kehidupan masyarakat. pemerintah sudah melakukannya bukan hanya lewat kebijakan, namun pertemuan-pertemuan dan juga mendengar apa yang menjadi kehendak warga masyarakat.

Human relations yang berfungsi sebagaimana mestinya antara lain faktor yang mendasari interaksi sosial dimana melibatkan individu secarafisik maupun psikologis, kemudian faktor yang menentukan interaksi sosial dengan caramenggunakan komunikasi antar individu atau komunikasi interpersonal.Hal itu yangkiranya belum bisa dimanfaatkan oleh pemerintah Distrik Mariat Kabupaten Sorong dalam menyelesaikan setiap masalah yang ada.

\section{KESIMPULAN}

Fungsi human relations sebagai penunjang dalam penyelenggaraan Pemerintah Distrik Mariat Kabupaten Sorong telah menunjukkan pelaksanaan relasi personal antara warga masyarakat dengan pemerintah sehingga membantu proses pembangunan masyarakat menunjukkan pelaksanaan relasi antar masyarakat dengan pemerintah yang baik. Human relations yang baik adalah adanya suatu interaksi, bukan sekedar relasi atau hubungan yang pasif, untuk mengembangkan hasil yang lebih produktif dan memuaskan. Human relationsyaitu tentang pola-pola perilaku dalam organisasi hendak menciptakan upaya saling pengertian baik untuk mewujudkan suatu kerjasama antara keseluruhan unsur manusia dalam organisasi, karna human relations bertujuan untuk mempermudah tercapainya tujuan organisasi, landasan setiap hubungan yang diciptakan atas dasar saling menghargai, sebab manusia memiliki martabat dan harga diri.

\section{SARAN}




\section{Jurnal Noken, Volume 4 (1) Halaman 12-22 2018}

Dalam menjalankan fungsi human relations dapat memenuhi kebutuhan masyarakat pada dasarnya meliputi kebutuhan ekonomi, psikologis dan sosial. Yang dialami masyarakat Distrik Mariat Kabupaten sorong, banyak kebutuhan yang menjadi keinginan masyarakat.Oleh karena itu, maka pemerintah bukan hanya menjalin komunikasi pasif melalui penyampaianpenyampaian, namun harus menjumpai warganya dan langsung memberikan jawaban dalam tindakan atas kebutuhan masyarakat seperti kebutuhan ekonomi, kebutuhan psikologis, kebutuhan sosial dengan kebijakan di bidang sosial yang kongkret karena masyarakat Distrik Mariat Kabupaten Sorong mempunyai hak hidup makmu dan sejahtera sesuai dengan kebijakan pemerintahan.

\section{DAFTAR PUSTAKA}

Abdurrachman M.A, Oemi, 2001, “DasarDasar Public Relations", Citra Aditya Bakti, Bandung.

Brannen, Julia. 2005, “ Memandu Metode penelitian kualitatif \& Kuantitatif "Pustaka Pelajaran, Yogyakarta.
Danim Sudarwan, 2004, “ Motivasi Human

Relations Dan Pengawasan

SemangatKerja", PT Rineka

Cipta, Jakarta.

E.Utrecht, 1960, “Pengantar Administrasi

Negara Indonesia ", FHPM

Universitas Negeri Pradjadjaran,

Hal 68. Bandung.

Effendy, Onong Uchjana, 2003, “ Ilmu Komunikasi Teori Dan Praktek" , PT Remaja Rosdukarya, Bandung.

H.M. Faried Ali, 2006, “ Filsafat Administrasi”, PT Raja Grafindo Persada, Jakarta.

Hotman P.Sibuera, 2001, “ Asas Negara Hukum, Peraturan kebijakaan Asas-AsasUmum Pemerintahan Yang Baik“, Erlagga Hal 161. Jakarta.

H.A.W. Widjaya, 2002, “Komunikasi dan Hubungan Masyarakat” PT Bumi Aksara, Jakarta.

Hasan, Erliana, 2010, “Komunikasi Pemerintahan " PT, Rifka Aditama, Bandung.

Idrus, Muhammad, 2007, “ Metode penelitian Ilmu-Ilmu sosial (PendekatanKualitatif dan 


\section{Jurnal Noken, Volume 4 (1) Halaman 12-22 2018}

Kuantitatif) . UII Press,

Yogyakarta.

Inu Kencana Syatiie, 2002, “ Sistem

Pemerintahan Indonesia",

Rineka Cipta,

Jakarta.

Inu Kencana Syafiie, 2007, “ Ilmu

Pemerintahan, Edisi Revisi"

mandar maju, bandung.

Johanes Usfunan, 2002, “ Perbuatan

Pemerintah Yang Dapat di

Gugat “ , Djambatan, Hal 139,

Surabaya.

Moh, Kusnadi dan Hermaily Ibrahim, 1983,

“ Pengantar Hukum Tata

NegaraIndonesia “ , Pusat Studi

Hukum Universitas Indonesia

dan CV Sinar bakti. Jakarta.

Sugiyono, 2008, “ Memahami Penelitian

Kualitatif", Alfabeta, Bandung.

Santoso.P.B, 1993, “ Birokrasi Pemerintah

Orde Baru PerspektipKultural danStruktural “, Bina Aksara, Jakarta.

Sondang P. Siagian, 2007, “ Administrasi Pembangunan Konsep, Dimensi, danStrategisnya", PT Bumi Akasara, Jakarta.
Surianigrat. Bayu, 1992, "Mengenal Ilmu

Pemerintahan" Aksara Baru 3, Jakarta.

Sudirman Ermaya, 2004, “Manajemen Pemerintahan Dan Ilmu Pemerintahan", CV Ramadhan, Bandung. 